\author{
W. Kucharczyk ${ }^{1}$, W. Żurowski ${ }^{1}$, R. Gumiński ${ }^{1}$, P. Przybyłek ${ }^{2}$, A. Komorek ${ }^{2}$ \\ ${ }^{1}$ Kazimierz Pulaski University of Technology and Humanities in Radom, Faculty of \\ Mechanical Engineering, Stasieckiego Street 54 B1, 26-600 Radom, Poland \\ ${ }^{2}$ Polish Air Force Academy, Faculty of Aviation, Dywizjonu 303 Street, No 12, 08-521 Dęblin, \\ Poland \\ wojciech.kucharczyk@uthrad.pl
}

\title{
EFFECT OF GLASS-FABRICS AND HIGH-MELTING POWDER FILLERS ON THERMAL PROTECTIVE PROPERTIES OF THERMOSETTING LAMINATES
}

\begin{abstract}
The present work investigates the ablative and thermal properties of phenol formaldehyde glass-fabrics laminates filled with mixtures of corundum $\mathrm{Al}_{2} \mathrm{O}_{3}$ and carbon $\mathrm{C}$ powders. The laminates specimens of dimensions $10 \times 25 \times 35 \mathrm{~mm}$ were treated with hot combustion gases having a temperature of more than $2800^{\circ} \mathrm{C}$. The carbonization of the thermosetting matrix was observed. Statistical methods for planning experiments were used, and the effect of components on the average rate of ablation, the maximum back side temperature of specimen and the average mass waste under intensive heat flow after $30 \mathrm{~s}$ of treatment with hot combustion gases was established. The best thermal protective properties were exhibited by the laminate containing 30\% matrix, 25\% fibre glass-fabric reinforcement, $9 \%$ corundum, and 36\% carbon powder.
\end{abstract}

Keywords: ablative shields and coats, thermosetting glass laminates, high-melting fillers

\section{INTRODUCTION}

The use of modified plastics as ablative materials protecting against excessive temperature increase was connected with the middle of XX century, directly with arms industry as well as aeronautical, rocket and space techniques $[1,2]$. These materials can also be used in the design of passive fire-proof protections for large cubature supporting elements in building structures [3], communication tunnels [4, 5] and for the protection of data stored in electronic, optical and magnetic carriers [6].

The development of compositions, manufacturing technologies and research into the characteristics of ablative materials has become of great importance due to the threat of terrorists attacks. It is in the USA that the analysis of the causes and consequences of such disastrous events as Oklahoma City or World Trade Centre attacks [3] or explosions of inflammable materials (fires in the Alps tunnels: St. Gotthard, St. Bernard, the tunnel under the Mont Blanc between 1999 and 2001 [4, 5]) has brought about a thorough scientific 
investigation into the behavior of such materials [7-10].

ITA (International Tunneling Association) recommends that the fire-resistant covers of fire-safety systems in tunnels should limit temperature growth of concrete to $350^{\circ} \mathrm{C}[4,5]$ (higher temperatures reduce concrete rigidity even below $50 \%$ of its nominal values [11]) and protect it against flaking and peeling. The steel structural elements must not exceed $300^{\circ} \mathrm{C}$ [4], as tensile strength and rigidity of steel diminish rapidly at higher temperatures. Carbon steel may exhibit as much as 6 to 8 times lower durability and nearly twice lower rigidity [6] at above $800^{\circ} \mathrm{C}$ (temperature of a typical office block fire [3]).

Good protective (fire- and thermal-buffer) properties can be attained using composite polymer coatings with typical ablative composite matrices (phenol resins [12-14], epoxy resins [15-19]) including fillers increasing thermal stability of a composite [12-20]. Once the ablation temperature of $\sim 200^{\circ} \mathrm{C}$ is exceeded by polymer resins, endothermic reactions are initiated that raise their effective specific heat considerably. Pure resins are good ablative materials. They require reinforcement, however, due to their low decomposition temperature, porosity and fragility of the ablative layer produced. Powders [12, 15, 17, 21-23] or fibre fillers $[13,14,16,24,25]$ or reinforcing plates $[25,26]$ of high melting temperatures build a composite structure that substantially improves thermal protective and thermal mechanical properties of a polymer ablative composite.

The ablation process is the process of exchanging of heat and mass which, due to physical changes and chemical reactions, results in chemical and structural changes of the material with simultaneous heat absorption, which reduces heating up of the material below the front of ablation. The heat influx causes relocation of the ablation front deeper into the material and thickening of the porous ablative surface. [6,27]

In the paper [27] Yu. I. Dimitrienko proposed a classification of ablation processes in composites treated with heat fluxes. The process of mass loss $m=\rho \cdot V$ (where $\rho$ is density and $\mathrm{V}$ is volume) due to the heat and thermo-mechanical impact of gas fluxes may result in a change in either density or volume as well as in a simultaneous change of both values.

The process of density loss where the volume remains unchanged is a pyrolysis which occurs in temperatures $500-1000^{\circ} \mathrm{C}$ and is characteristic for polymer composites. Such a process is called volumetric ablation. The process in which there occurs a volume loss with unchanged density is called surface ablation. It is typical for oxidization o graphite, metals and their alloys, glass as well as some types of fusible ceramic materials. A simultaneous occurrence of both processes of thermal degradation is referred to as combined ablation. Combined ablation usually takes place in high temperatures $\left(1000-1500^{\circ} \mathrm{C}\right)$ and results from thermal and erosive gas impact. In all of the above-mentioned cases there occur ablative wear (which is sometimes purely erosive) of the basic material. [27]

To be able to take the full advantage of ablative materials we need to be aware of their ablative wear characteristics, which have to be taken into consideration at the early stage of the technological design. This includes a loss in active volume of the material that is not subject to ablation. The effect is characterized by linear ablation rate $v_{a}[\mu \mathrm{m} / \mathrm{s}]$ defined as the average rate of dislocation of the ablation front i.e. the average rate of formation of ablative surface and so-called vitreous slag. If we determine the rate of ablation it is possible to determine the temporary location of the ablation front and, in consequence, to determine the thickness of active insulating layer [9, 28].

Despite many years of experience with ablative materials, the relationship between the phases type and composition with ablative properties, within the context of others operational properties of the composites used as thermal protection shields, remains still not evaluated qualitatively and quantitatively $[1,4,7]$. 


\section{EXPERIMENTAL METHODS}

The following materials (input variables $\mathrm{x}_{\mathrm{i}}$ ) have been used to prepare the specimens of thermosetting glass laminates with powder fillers: two kinds of phenol formaldehyde resins (liquid resin Modofen 54S and adhesive resin Nowolak MR in mass proportions 1:1) for matrix; glass-fabric $\left(250 \mathrm{~g} / \mathrm{m}^{2}\right)$ as fibre reinforcement; as well as powder fillers, corundum $\mathrm{Al}_{2} \mathrm{O}_{3}$ with grains of 2 to $5 \mu \mathrm{m}$ with the minimal contents of aluminium oxide of $99.5 \%(95 \%$ $\alpha \mathrm{Al}_{2} \mathrm{O}_{3}$ ) and fine grain carbon powder $\mathrm{C}$ of $5 \mu \mathrm{m}$ and purity of $98 \%$.

The number of sample phase compositions, equal to the number of scheduled experiments $(\mathrm{N}=8)$, was determined on the basis of the adopted design of experimentation, i.e. an orthogonal $1^{\text {st }}$ order full-factorial matrix of the type $2^{3}=8$ including single replications, where two state levels (lower level -1 and upper level +1 ) and three independent input variables $\left(\mathrm{x}_{\mathrm{i}}\right)(\mathrm{i}=1,2,3)$ occur, determined by means of the mathematical dependence (1) [29]:

$$
\mathrm{x}_{\mathrm{i}}=\frac{\mathrm{x}-\overline{\mathrm{x}}_{\mathrm{i}}}{\Delta \mathrm{x}_{\mathrm{i}}}= \pm 1
$$

with

$\mathrm{x}_{1}-$ mass contents of the matrix: $24 \%$ (level -1$)$ and $30 \%($ level +1$), \Delta \mathrm{x}_{1}=3 \%$;

$\mathrm{x}_{2}-$ number of glass-fabrics layers: 8 layers (level -1) i 12 layers (level +1$) ; \Delta \mathrm{x}_{2}=2$;

$\mathrm{x}_{3}$ - mass proportion of $\mathrm{Al}_{2} \mathrm{O}_{3}$ corundum to the total mass of both fillers $\mathrm{Al}_{2} \mathrm{O}_{3} /\left(\mathrm{Al}_{2} \mathrm{O}_{3}+\mathrm{C}\right)$ :

$20 \%$ (level -1) and $80 \%($ level +1$), \Delta \mathrm{x}_{3}=30 \%$.

The components of the response variable $\mathrm{y}_{\mathrm{i}}\left(\mathrm{x}_{\mathrm{i}}\right)$ (the output parameters) are: the average rate of ablation $\mathrm{v}_{\mathrm{a}},(\mu \mathrm{m})$, the average maximal temperature of the rear surface of specimen $\mathrm{t}_{\mathrm{s} \_\max },\left({ }^{\mathrm{O}} \mathrm{C}\right)$ and an average relative ablative (erosive) mass loss $\mathrm{U}_{\mathrm{a}},(\%)$ after $30 \mathrm{~s}$ of treatment with hot combustion gases.

The so-called "ablative gun" [30] of our own construction stand [6] has been used for the

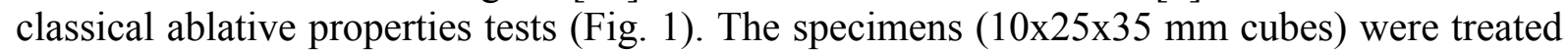
of oxy-acetylene mixture of hot combustion gases having a temperature of more than $2800^{\circ} \mathrm{C}$ during 30 seconds.

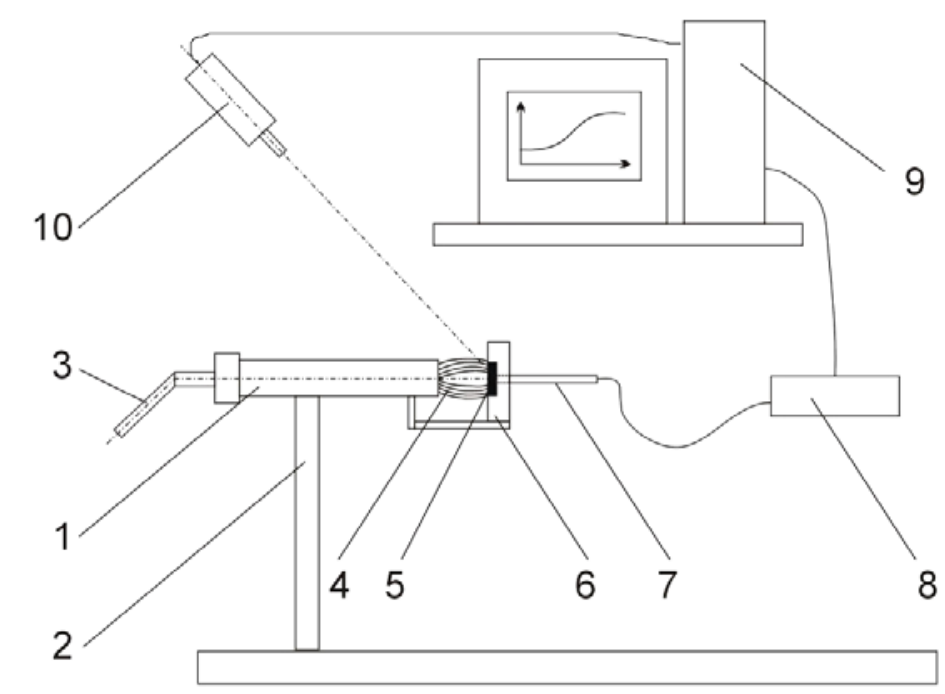

Fig. 1. Measurement stand: 1 - the ablative gun with flammable gases stabilization, $2-a$ tripod, $3-a$ torch, 4 - a flame, 5 - the testing sample, 6 - a sample casing, 7 - the thermocouple, 8 - the temperature measurer of $t_{s}(\tau), 9-a$ computer, 10 - the pyrometer and the thermovision camera to $t_{p a}(\tau)$ measurement 


\section{RESULTS AND DISCUSSION}

The registration of the back side temperature $\left(t_{s}\right)$ of specimen have been performed (Fig. 2). Furthermore, the average rate of ablation $\left(\mathrm{v}_{\mathrm{a}}\right)$ and the average ablation mass waste of laminates $\left(\mathrm{U}_{\mathrm{a}}\right)$ has been also evaluated. There are three output variables, components of the response function (Table 1).

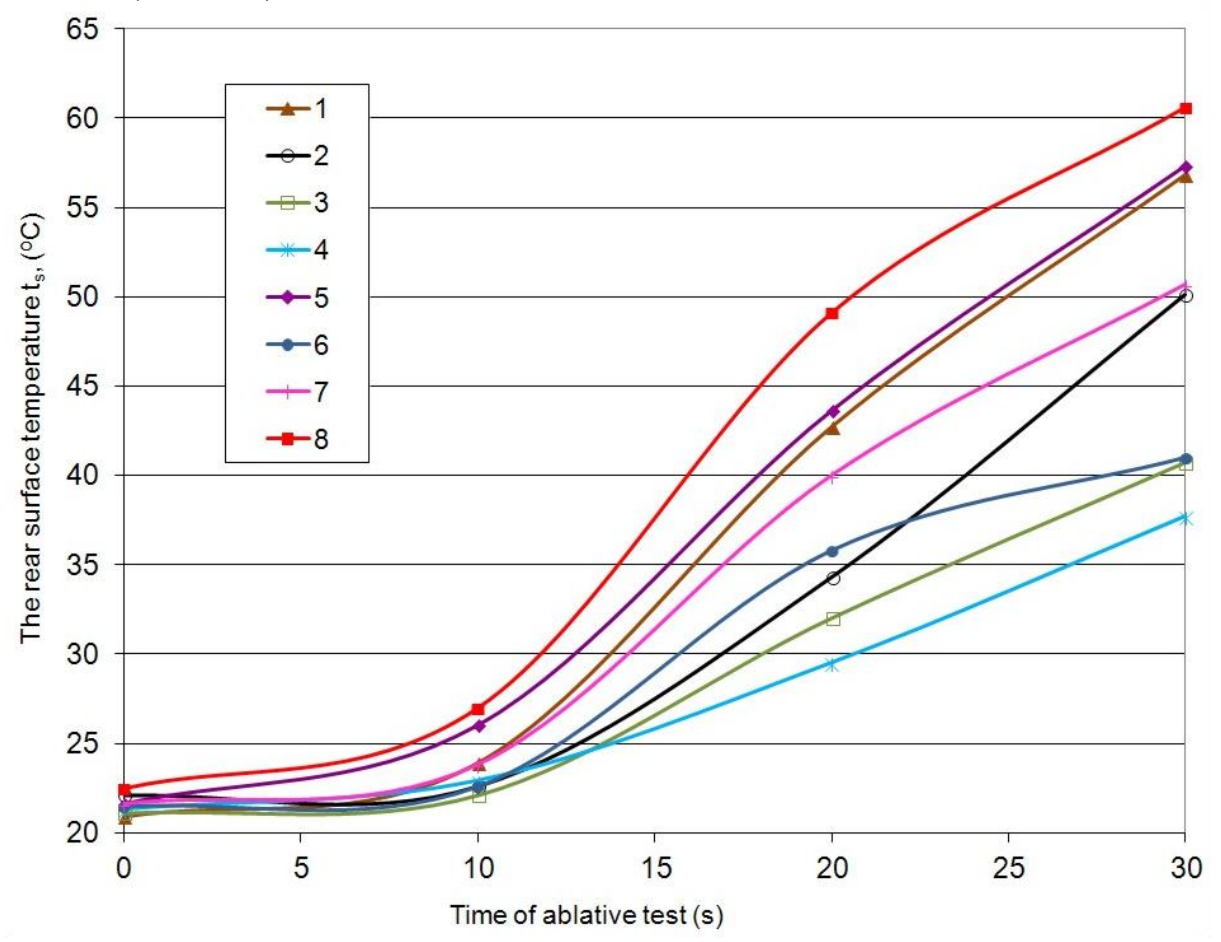

Fig. 2. Changing of the rear surface temperature ts during $30 \mathrm{~s}$ of the heat flux exposition

The greatest temperature growth, $t_{\mathrm{s}}$, was recorded for composite 8 and the lowest for specimen 4 in the entire duration of the 30 -second-long ablative test. The final greatest temperatures, $\mathrm{t}_{\mathrm{s} \max }$, of the same specimens are maximum and minimum, respectively. The variable $\mathrm{x}_{3}$ - relation of $\mathrm{Al}_{2} \mathrm{O}_{3}$ mass to the sum total of masses of both the fillers $\left(\mathrm{Al}_{2} \mathrm{O}_{3}+\mathrm{C}\right)$ - is the composition parameter than clearly differentiates both the specimens. Specimen 4 contains more than 3.5 times more carbon powder and more than 4.5 times less of corundum than specimen No. 8.

Table 1. The results of ablation (thermal protective) tests

\begin{tabular}{|c|c|c|c|c|c|c|c|c|c|}
\hline & & \multicolumn{8}{|c|}{ Number of test } \\
\hline \multicolumn{2}{|c|}{ Parameter } & 1 & 2 & 3 & 4 & 5 & 6 & 7 & 8 \\
\hline \multicolumn{2}{|c|}{ Matrix $\left(\mathrm{x}_{1}\right)[\%]$} & 24 & 30 & 24 & 30 & 24 & 30 & 24 & 30 \\
\hline \multicolumn{2}{|c|}{ Fibreglass fabric $\left(\mathrm{x}_{2}\right)[\%]$} & 18 & 18 & 25 & 25 & 13 & 13 & 19 & 19 \\
\hline \multirow{2}{*}{$\begin{array}{l}\text { Powder fillers } \\
\left(\mathrm{x}_{3}\right)[\%]\end{array}$} & $\mathrm{Al}_{2} \mathrm{O}_{3}$ & 11.6 & 10.4 & 10.2 & 9.0 & 50.4 & 45.6 & 45.6 & 40.8 \\
\hline & $\mathrm{C}$ & 46.4 & 41.6 & 40.8 & 36.0 & 12.6 & 11.4 & 11.4 & 10.2 \\
\hline \multicolumn{2}{|c|}{$\mathrm{v}_{\mathrm{a}}[\mu \mathrm{m} / \mathrm{s}]$} & 121 & 158 & 125 & 128 & 130 & 166 & 157 & 172 \\
\hline \multicolumn{2}{|c|}{$\mathrm{t}_{\mathrm{s} \_\max }\left[{ }^{\circ} \mathrm{C}\right]$} & 56.8 & 50.1 & 40.7 & 37.7 & 57.3 & 41.0 & 50.7 & 60.6 \\
\hline \multicolumn{2}{|c|}{$\mathrm{U}_{\mathrm{a}}[\%]$} & 10.8 & 11.0 & 9.6 & 8.3 & 6.9 & 5.9 & 6.7 & 7.3 \\
\hline
\end{tabular}


The aim of the experiment was to find such a composite whose values of the average ablation rate $\mathrm{v}_{\mathrm{a}}$, the maximum back side temperature $\mathrm{t}_{\mathrm{s} \text { max }}$ and the average mass waste $\mathrm{U}_{\mathrm{a}}$ are the lowest. These conditions have been fairly met by specimen 4 whose phase composition consists of $30 \%$ matrix, $25 \%$ fibre glass fabric reinforcement, $9 \%$ corundum $\mathrm{Al}_{2} \mathrm{O}_{3}$, and $36 \%$ carbon powder $\mathrm{C}$ (Fig 3).

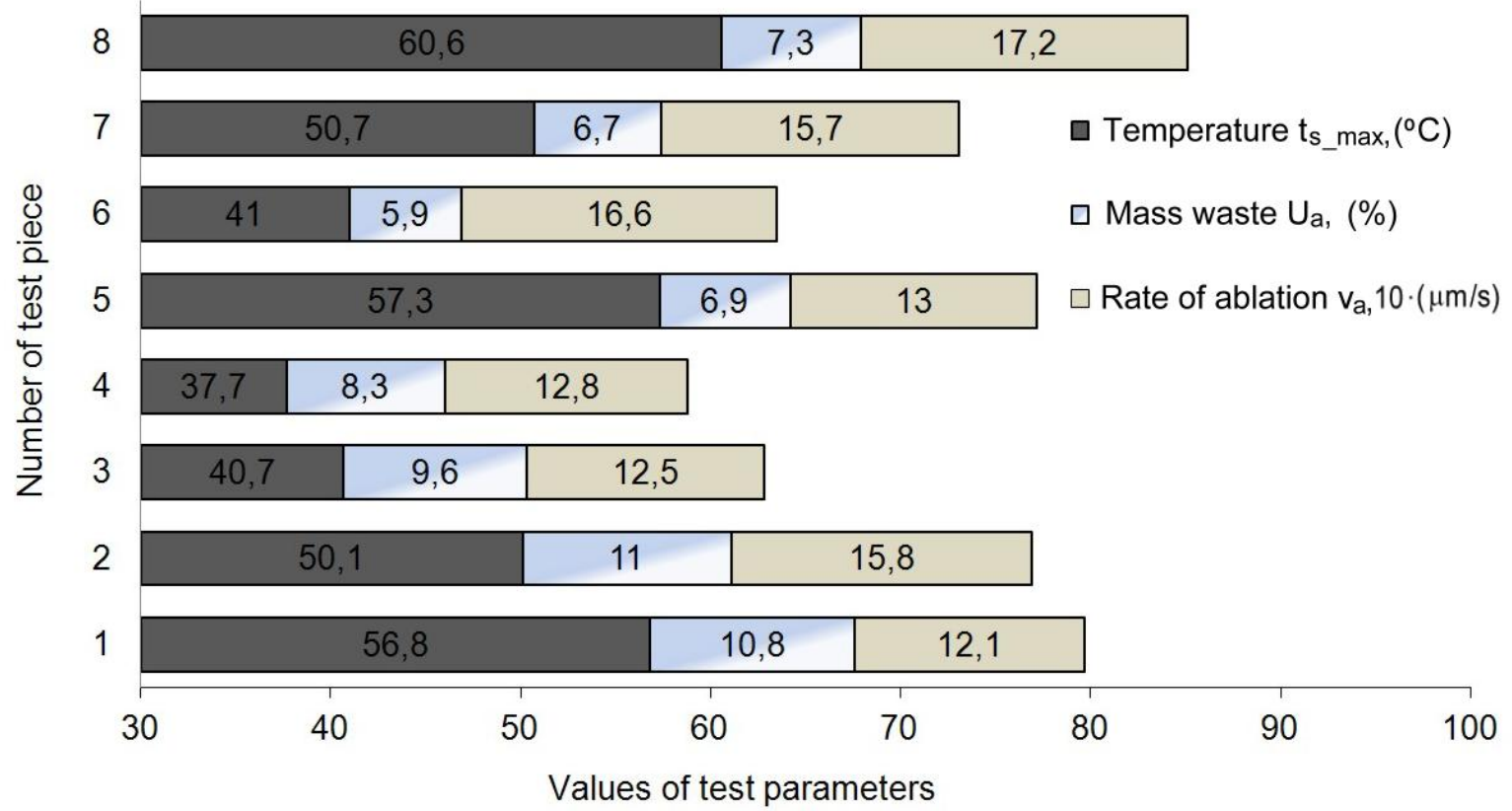

Fig. 3. Results of ablative research: the max. temperature $t_{s_{-} \max }$, the mass waste $U_{a}$ and the rate of ablation $v_{a}$

The evaluation of ablative thermal protection properties of thermosetting glass laminates were carried out on the basis on a first order $2^{3}$ statistical experimental research program. The regression coefficients of all function components have been calculated. The statistical analysis of the tests results allowed the determination of the threshold relevance of the regression coefficients $b_{i}$ and estimation of their effect on the thermal protection properties.

Moreover, the variance $\mathrm{s}^{2}(\mathrm{y})$, error in determination regression and interaction coefficients $s\left(b_{i}\right)$ and their level of statistical significance $\left(b_{\text {sign }} \geq b_{i}\right)$ have been determined on the basis of t-Student test at confidence level $\alpha_{p}=0.05$ (Table 2) [29].

Table 2. Statistics of coefficients the equations of the response variable

\begin{tabular}{|c|c|c|c|c|c|c|c|c|c|c|c|}
\hline Function $\mathrm{y}_{\mathrm{i}}$ & $\mathrm{b}_{0}$ & $\mathrm{~b}_{1}$ & $\mathrm{~b}_{2}$ & $\mathrm{~b}_{3}$ & $\mathrm{~b}_{12}$ & $\mathrm{~b}_{13}$ & $\mathrm{~b}_{23}$ & $\mathrm{~b}_{123}$ & $\mathrm{~s}^{2}(\mathrm{y})$ & $\mathrm{s}\left(\mathrm{b}_{\mathrm{i}}\right)$ & $\mathrm{b}_{\text {sign }}$ \\
\hline $\mathrm{v}_{\mathrm{a}}[\mu \mathrm{m} / \mathrm{s}]$ & 144.5 & 11.4 & - & 11.5 & -6.9 & - & 7.5 & - & 47.61 & 2.4 & 5.6 \\
\hline $\mathrm{t}_{\mathrm{s} \_ \text {max }}\left[{ }^{\circ} \mathrm{C}\right]$ & 49.3 & -2.02 & -1.93 & 3.06 & 3.74 & - & 5.19 & 2.82 & 5.81 & 0.85 & 1.96 \\
\hline $\mathrm{U}_{\mathrm{a}}[\%]$ & 8.29 & -0.17 & -0.34 & -1.61 & - & 0.09 & 0.63 & 0.39 & 0.04 & 0.07 & 0.16 \\
\hline Equations & \multicolumn{7}{|c}{$\mathrm{y}_{\mathrm{i}}\left(\mathrm{x}_{\mathrm{i}}\right)=\left(\mathrm{b}_{0}+\mathrm{b}_{1} \mathrm{x}_{1}+\mathrm{b}_{2} \mathrm{x}_{2}+\mathrm{b}_{3} \mathrm{x}_{3}+\mathrm{b}_{12} \mathrm{x}_{1} \mathrm{x}_{2}+\mathrm{b}_{13} \mathrm{x}_{1} \mathrm{x}_{3}+\mathrm{b}_{23} \mathrm{x}_{2} \mathrm{x}_{3}+\mathrm{b}_{123} \mathrm{x}_{1} \mathrm{x}_{2} \mathrm{x}_{3}\right) \pm \mathrm{s}(\overline{\mathrm{y}})$} \\
\hline
\end{tabular}

Analysis of the interaction and regression coefficients indicates:

- The type of loose filler used $\left(b_{3}\right)$ has the greatest effect on ablative thermal protective properties - a higher share of carbon at the expense of corundum reduces both the rate of ablation $\mathrm{v}_{\mathrm{a}}$ and temperature $\mathrm{t}_{\mathrm{s}_{-} \max }$. 
- The proportion of composite matrix $\left(b_{1}\right)$ is of equal importance - a reduction of resin content does increase $v_{a}$ yet lowers $t_{s_{-} \text {max }}$.

- Simultaneously increasing the resin content and number of fabric layers, and the consequent lower share of powder fillers $\left(b_{12}\right)$, slows $\mathrm{v}_{\mathrm{a}}$ and raises the temperature of the specimen back side, $t_{s_{\text {s }} \text { ax }}$, without clearly affecting the ablative mass waste $\mathrm{U}_{a}$;

- Raising the number of fabric layers and $\mathrm{Al}_{2} \mathrm{O}_{3}$ content (a lower content of $\mathrm{C}$ ) impairs the thermal protective properties $\left(\mathrm{b}_{23}\right)$ - all the three parameters rise.

Figure 4 is an example of a graphical interpretation of the dependence of $v_{a}$ on phase compositions of the tested composites. Changing value of the independent variable $\mathrm{x}_{\mathrm{i}}$ alters, to a greater or lesser extent, the rate of ablation in accordance with the component function equation expressed for the test object, $\mathrm{v}_{\mathrm{a}}\left(\mathrm{x}_{\mathrm{i}}\right)$.
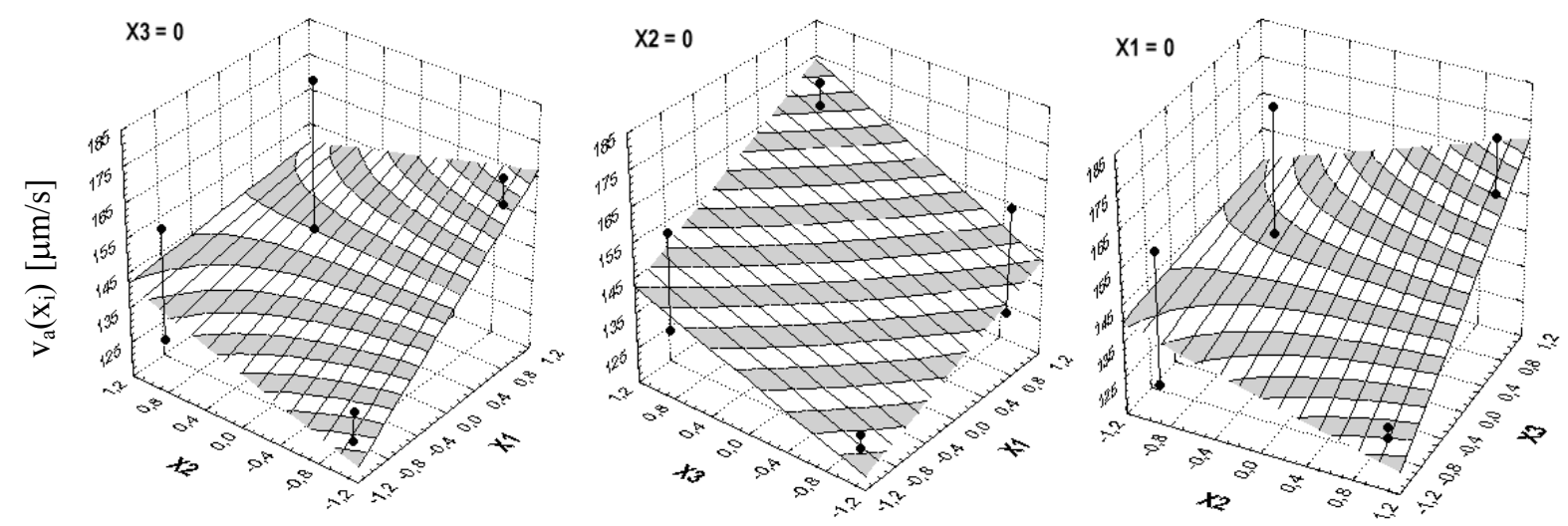

Fig. 4. Diagrams of the dependences $v_{a}\left(x_{i}\right)=\left(144.5+11.4 x_{1}+11.5 x_{3}-6.9 x_{1} x_{2}+7.5 x_{2} x_{3} \pm 6.9\right) \mu \mathrm{m} / \mathrm{s}$, in a set of code variables $x_{i}$

\section{STRUCTURES OF ABLATIVE SAMPLES}

Experimental samples after the ablation process were covered with chemically crosslinked resin in cylindrical moulds (plastic tubes). After hardening the resin, it was cut along the heat flux direction in the symmetry axis of the ablative surface. Samples were cut mechanically at slow speed and with cooling to avoid temperature increase in the crosssection, which could affect the structure and thermal stability of the polymer. Next, samples were wet polished using sandpaper with decreasing grain size and then wet polished using felt with polishing paste (corundum). No corrosives were used. Then pictures of the ablative layer structures and the basic material were taken using an optical microscope.

Photo 1 shows an ablative surface where secondary ablation processes have taken place, including melting of complex ceramic structures produced by impact of heat from silica compounds (contained in a glass-fabric) and the powder fillers: aluminium oxide $\mathrm{Al}_{2} \mathrm{O}_{3}$ and carbon dust $\mathrm{C}$ as well as carbon arising from the process of matrix pyrolysis. Solidified layers of ceramic 'fans' (light, irregular bands in the upper parts of the specimens) can be seen. An area of the so-called vitreous slag - a porous substance of low thermal conductivity, solid product of pyrolysis and secondary ablation - is apparent in the ablative layer's structure below. 

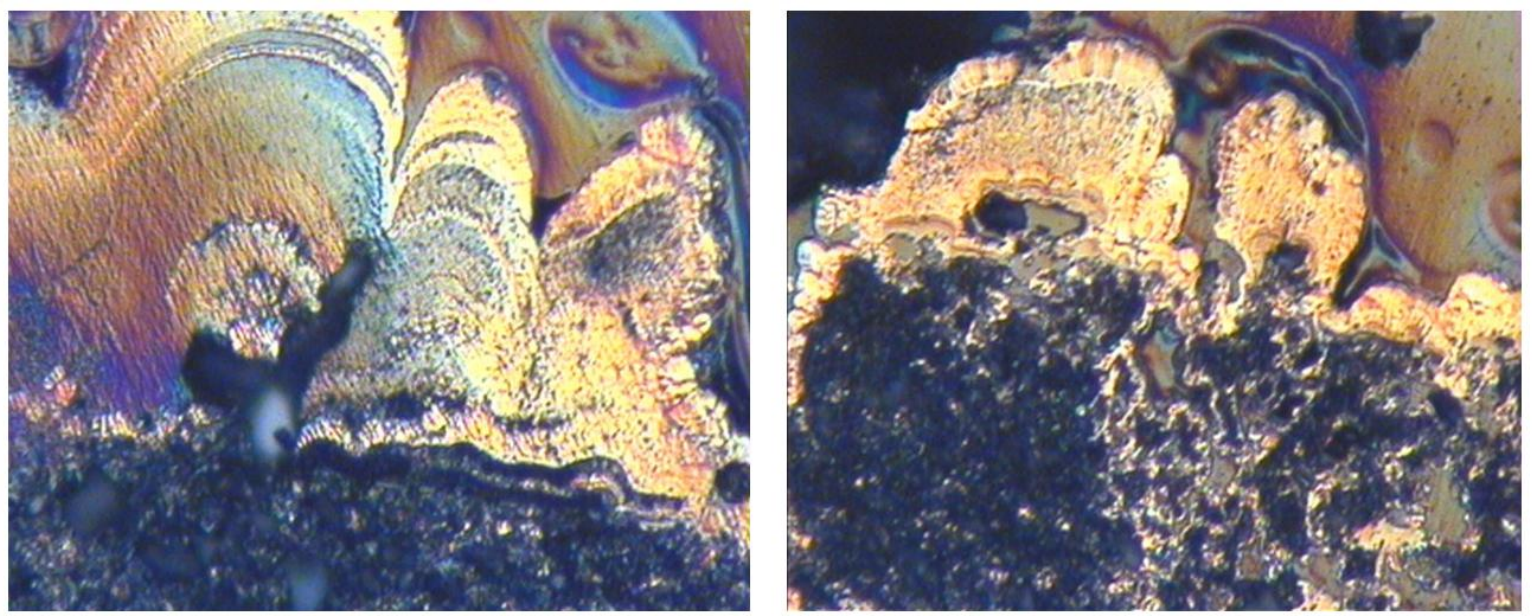

Fig. 5. Structure of specimen 6's ablative surface after an ablation time of 30s with apparent 'fans' of solidified ceramic layers, amplified. Magn. x250

The boundary between primary and secondary ablation in the ablative layer can be noted in Fig. 5a and 5b. In Fig. 6a, the front of secondary ablation has come to a halt between layers of the fabric, i.e. against loose particles. The vitreous slag (the dark area of primary ablation) is situated below the solidified ceramic compounds (the light area of secondary ablation). Figure $6 \mathrm{~b}$ shows ablation to have stopped at the fabric layer - only fibres along the surface of the specimen microsection are melted. A solidified, fine-grained ceramic structure, a zone of transformations and secondary reactions, nearly free from solid products of pyrolysis, can be seen above the fabric. It can be surmised only the resin matrix of the composite has decomposed beneath the fabric's longitudinal fibres, while the temperature there has not risen locally above $700^{\circ} \mathrm{C}$ (the fibres do not display softening).
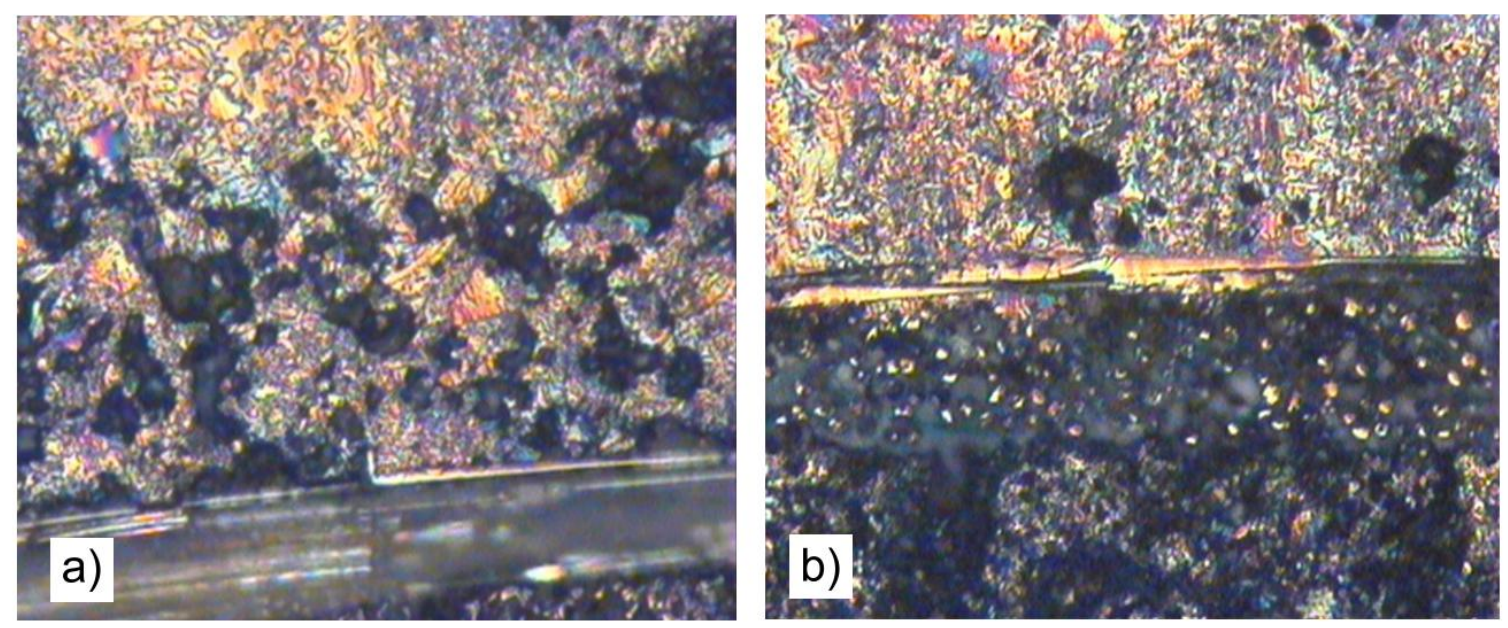

Fig. 6. Ablation front: a) between the glass-fabric layers, specimen 2, b) on the glass-fabric boundary, specimen 3. Magn. $\times 250$

Native material of the composite which has not undergone the process of ablation is illustrated in Photo $3 \mathrm{a}$ - large, light, angular grains of the corundum $\mathrm{Al}_{2} \mathrm{O}_{3}$ powder filler can be seen against the background of black carbon dust $\mathrm{C}$ and structural defects - bubbles generated in the production process. Transverse reinforcing fibres (the circular structures in 
the right upper part of the photo) can also be seen.

The fine-grain structure of the solidified ceramics (secondary ablation) with typically dendritic grains (the light areas) is apparent in Fig.7 against the background of the dark, porous vitreous slag (the material residue of the primary ablation process). The ceramic grains have not sharp but obtuse edges, evidence they are produced by chemical reactions of the secondary ablation substrates (based on carbon, corundum and silica compounds), followed by solidification when the effect of the heat flux can no longer be felt.
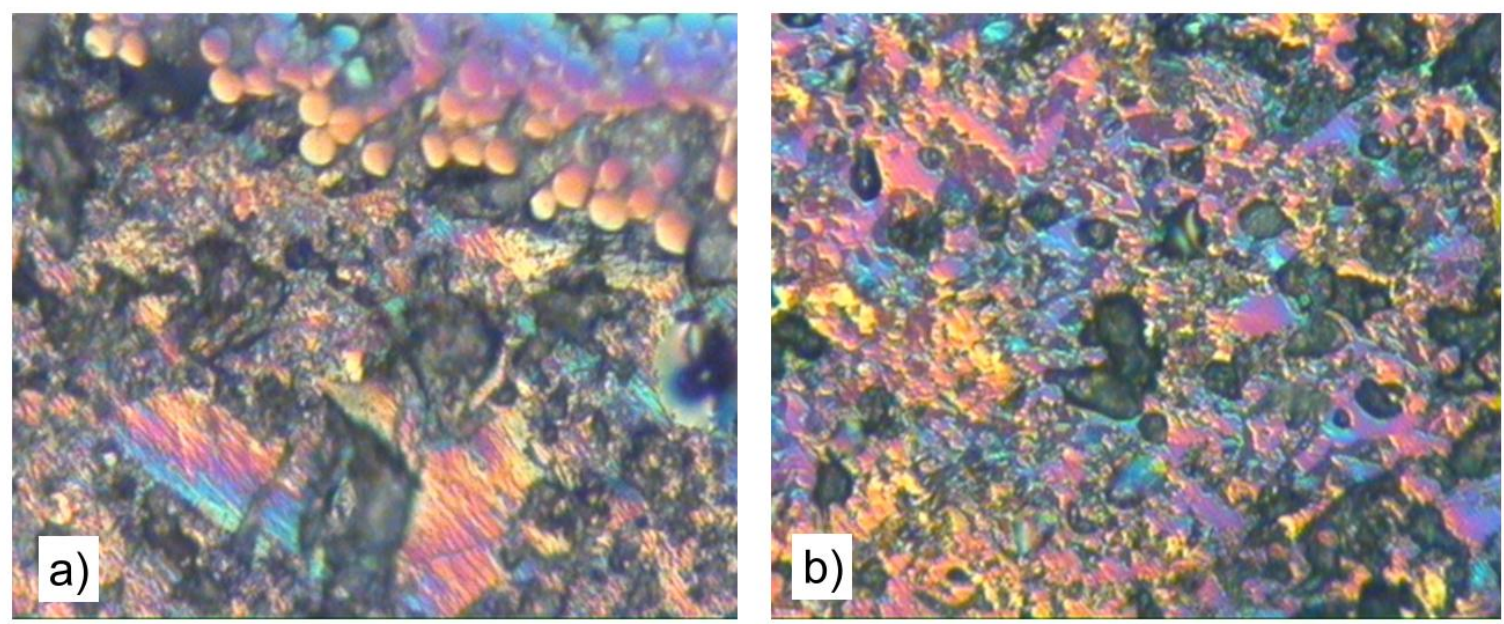

Fig. 7. Ablative specimen: a) native material, b) ablative layer, specimen 1. Magn. x250

\section{CONCLUSIONS}

1. The best thermal protective properties, i.e. the average ablation rate and simultaneously the lowest temperature of the rear surface area, how also the lowest ablative weight loss (the highest thermal stability) were exhibited by the thermosetting hybrid laminate containing $30 \%$ matrix, $25 \%$ fibre glass-fabric reinforcement, $9 \%$ corundum $\mathrm{Al}_{2} \mathrm{O}_{3}$, and $36 \%$ carbon powder C.

2. The type of loose filler applied shows the greatest impact on boosting thermal protective properties of the tested composites. Increasing the share of phase carbon at the expense of corundum is recommended, while preserving the average proportion of the glass-fabric layers.

3. Preserving the average number of glass-fabric layers (variable $\mathrm{x}_{2}$ ) is statistically reasonable, however, application of the same number of glass-fabric layers though with a lower area density would be indicated for further experimentation - this would allow for increasing the shares of both the matrix and loose fillers.

4. For technological reasons and due to values of the coefficient $\left(b_{1}\right)$, the resin content should not be modified though it is acceptable and even recommended (especially if a fabric with a lower area density is used) given the higher share of carbon dust.

5. There is no straightforward mutual impact of the independent variables $x_{i}$ on thermal destruction of the material, although characteristics of thermal protective material ablation are apparent (Fig. 5-7), with the thermal energy flux expended on: thermal degradation and pyrolysis of the composite matrix; melting of the glass-fabric and decomposition of silica compounds; thermal-chemical generation of new ceramic structures based on silica, carbon 
and corundum; phase transitions of the chemical products and other material components which have not been decomposed; creation of a passive thermal protective layer with a low thermal conductivity (vitreous slag).

\section{REFERENCES}

1. Soutis C.: Fibre reinforced composites in aircraft construction. Progress in Aerospace Sciences, (2005) 143-151.

2. Butler BD, Winter M, Panerai F, Martin A, Bailey SC, Stackpoole M, Denehy PM, Splinter S.: Characterization of candidate materials for remote recession measurements of ablative heat shield materials, 54th AIAA Aerospace Sciences Meeting, San Diego, California, USA, 2016. http://dx.doi.org /10.2514/6.2016-1516

3. NIST NCSTAR 1.: Final report on the Collapse of the World Trade Center. U.S. Government Printing Office, Washington, 2005. Retrieved Jun 12, 2006, from http://www.nist.gov/manuscript -publication-search.cfm?pub_id $=909236$

4. Ono K, Otsuka T. Fire design requirement for various tunnel. Authors' presentation of 32nd ITA World Tunnel Congress, Seoul, Republic of Korea. Retrieved Jun 23, 2006, from www.ita2006.com.

5. Haack, A. (2004). Latest achievements and perspectives in tunnel safety. Tunneling Underground Space Technology, 19 (204) 305. http://dx.doi.org/10.1016/j.tust.2004.01.007.

6. Kucharczyk W.: Kształtowanie ablacyjnych właściwości termoochronnych kompozytów polimerowych napełniaczami proszkowymi. Rozprawa doktorska. Politechnika Radomska, Radom, 2007.

7. Firmo JP, Correia JR. Fire behaviour of thermally insulated RC beams strengthened with EBR-CFRP strips: Experimental study. Composite Structures, 122 (2015) 144-154. http://dx.doi.org/10.1016/j.compstruct.2014.11.063

8. Kucharczyk W, Dusiński D, Żurowski W, Gumiński R.: Effect of composition on ablative properties of epoxy composites modified with expanded perlite. Composite Structures, 183 (2018) 654-662. http://dx.doi.org/10.1016/j.compstruct.2017.08.047

9. Bahramian A R, Kokabi M. Ablation mechanism of polymer layered silicate nanocomposite heat shield. Journal of Hazardous Materials, 166 (2009) 445-454. http://dx.doi.org /10.1016/ j.jhazmat.2008.11.061

10. Krzyżak A, Kucharczyk W, Gąska J, Szczepaniak R.: Ablative test of composites with epoxy resin and expanded perlite. Composite Structures, (2018). Accepted manuscript. https://doi.org /10.1016/j.compstruct.2018.05.018

11. Willam K, Rhee I, Shing B. Interface damage model for thermomechanical degradation of heterogeneous materials. Computer Methods in Applied Mechanics and Engineering, 193 (2004) 3327-3350. http://dx.doi.org/10.1016/j.cma.2003.09.020

12. Kucharczyk W, Przybyłek P, Opara TA.: Investigation of the thermal protection ablative properties of thermosetting composites with powder fillers: the corundum $\mathrm{Al}_{2} \mathrm{O}_{3}$ and the carbon powder $\mathrm{C}$. Polish Journal of Chemical Technology, 15(4) (2013) 49-53. http://dx.doi.org/10.2478/pjct2013-0067

13. Pulci G, Tirillň J, Marra F, Fossati F, Bartuli C, Valente T.: Carbon-phenolic ablative materials for re-entry space vehicles: Manufacturing and properties. Composites: Part A, 41 (2010) 1483-1490. http://dx.doi.org/10.1016/j.compositesa.2010.06.010 
14. Bahramian AR.: Effect of external heat flux on the thermal diffusivity and ablation performance of carbon fiber reinforced novolac resin composite, Iranian Polymer Journal, 22 (2013) 579-589. http://dx.doi.org/10.1007/s13726-013-0157-z

15. Bakar M, Kucharczyk W, Stawarz S.: Investigation of thermal and ablative properties of modified epoxy resins. Polymers \& Polymer Composites, 24(8) (2016) 617-623.

16. Kucharczyk W.: Wybrane właściwości ablacyjne kompozytów epoksydowych do zastosowań termoochronnych. Przemysł Chemiczny, 89(12) (2010) 1673-1676.

17. Camino G, Tartaglione G, Frache A, Manferti C, Costa G.: Thermal and combustion behaviour of layered silicate-epoxy nanocomposites. Polymer Degradation and Stability, 90 (2005) 354-362. http://dx.doi.org/10.1016/j.polymdegradstab.2005.02.022

18. Landowski M, Imielińska K.: Impact behaviour of glass fribre /epoxy composites with nanoenhanced resin after water exposure. Advances in Materials Science, 2(44) (2015) 30-35. http://dx.doi.org/10.1515/adms -2015-0010

19. Ashok Kumar M, Prasad AMK, Ravishankar DV, Giridhar G.: Characterization of composite laminates subjected to repeated indentation. Advances in Materials Science, 2(40) (2014) 46-56. http://dx.doi.org/10.2478/adms-2014-0009

20. Hörold A., Schartel B., Trappe V., Korzen M., Bünker J.: Fire stability of glass-fibre sandwich panels: The influence of core materials and flame retardants, Composite Structures, 160 (2017) 1310-1318. http://dx.doi.org/10.1016/j.compstruct.2016.11.027

21. Lombardi M, Fino P, Malucelli G, Montanaro L.: Exploring composites based on PPO blend as ablative thermal protection systems - Part I: The role of layered fillers. Composite Structures, 94 (2012) 1067-1074. http://dx.doi.org/10.1016/j.compstruct.2011.10.019

22. Kausar A.: Polyamide 1010/polythioamide blend reinforced with graphene nanoplatelet for automotive part application. Advances in Materials Science, 3 (53) (2017) 24-36. http://dx.doi.org/10.1515/adms-2017-0013

23. Fino P, Lombardi M, Antonini A, Malucelli G, Montanaro L.: Exploring composites based on PPO blend as ablative thermal protection systems - Part II: The role of equiaxial fillers. Composite Structures, 94 (2012) 1060-1066. http://dx.doi.org/10.1016/j.compstruct.2011.10.020

24. Alagar M, Ashok Kumar A, Mahesh KPO, Dinakaran K.: Studies on thermal and morphological characteristics of E-glass/Kevlar 49 reinforced siliconized epoxy composites. European Polymer Journal, 36 (2000) 2449-2454.

25. Minkook K, Jaeheon C, Dai Gil L.: Development of the fire-retardant sandwich structure using an aramid/glass hybrid composite and a phenolic foam-filled honeycomb. Composite Structures, 158 (2016) 227-234. http://dx.doi.org/10.1016/j.compstruct.2016.09.029

26. Anjang A, Chevali WS, Lattimer BY, Case SW, Case Feih S, Mouritz AP: Postfire mechanical properties of sandwich composite structures. Composite Structure, 132 (2015) 1019-1028. http://dx.doi.org/10.1016/j.compstruct.2015.07.009

27. Dimitrienko $\mathrm{Yu}$ I. Thermal stresses in ablative composite thin-walled structures under intensive heat flows. International Journal of Engineering Science, 35/1 (1997) 15-31. http://dx.doi.org /10.1016/S0020-7225(96)00071-7

28. Lin W-S. Steady ablation on the surface of a two-layer composite. International Journal of Heat and Mass Transfer, 48 (2005) 5504-5519.

29. Montgomery DC.: Design and analysis of experiments. Wiley, New York, 2009.

30. Song GM, Zhou Y, Wang Y-J.: Effect of carbide particles on the ablation properties of tungsten composites. Materials Characterization, 50 (2003) 293-303. http://dx.doi.org/10.1016/ S00143057(00)00038-0 